
Magdalena STĂNCULESCU, Marina MIHĂILĂ, Mihaela ZAMFIR

Teoria proiectului de arhitectură: de la discurs la educația academică

Theory of architectural design:

from discourse to academic education 


\section{Teoria proiectului \\ de arhitectură: \\ de la discurs la educația academică}

\section{Theory of architectural design: \\ from discourse to academic education}

\author{
Magdalena STĂNCULESCU (1) \\ Marina MIHĂILĂ (2) \\ Mihaela ZAMFIR (2) \\ magdalena.stanculescu@uauim.ro \\ marina.mihaila@arhitectonik.ro
} mihaela.zamfir@uauim.ro

(1) Conf.Dr.Arhitect, Director Departament SP* (2) Lector/Șef Lucrări Dr.Arhitect, SP*, FA UAUIM (1) Assoc.Prof.Dr.Architect, Director of SP*, Department,

(2) Lecturer Dr.Architect, SP*, FA UAUIM

*Departament Sinteza Proiectării de Arhitectură Facultatea de Arhitectură Universitatea de Arhitectură și Urbanism lon Mincu UAUIM București *Synthesis of Architectural Design Department (SP) Faculty of Architecture Ion Mincu University of Architecture and Urbanism UAUIM Bucharest

$$
\text { UAUIM Bucharest }
$$

Contextul lucrării este educația academică, nivel master integrat, și planurile de invățământ definite de Departamentul Sinteza Proiectării de Arhitectură (SP), Facultatea de Arhitectură, UAUIM București. Materialele și metodele definite de către Atelierele de Design Arhitectural/ Atelierele de Proiectare sunt completate cu o viziune integrată de cercetare prin design/cercetare prin proiect, în modelarea Teoriei Designului Arhitectural/ Teoriei Proiectului (de Arhitectură) (TP) pentru a fi accesibile studenților, oferind o înțelegere cuprinzătoare a scopului educației: viitori profesioniști arhitecți. Rezultatele și discuțiile focusează pe definirea unei deveniri în timp a noțiunii de teorie a designului arhitectural, exprimări provenite de la breslele profesionale către spaţiul academic, și invers, și în final pe definirea cercetării prin proiect, de a prezenta și a împărtăși rezultate și cunostințe inovative prin Cursul Teoria Proiectului (TP) în cadrul SP. Concluzii: între miezul discuților contemporane ale devenirii istorice a domeniului, o întreagă nouă educație academică targetează idei teoretice performante care susțin și rezultă direct din practică, ca cercetare prin proiect. Pentru că statutul procesului de design/ proiectare - prelegeri contextuale și principii, curățenia formei și noi metode de abordare- devin egal importante cu autonomia și originalitatea obiectului arhitectural și a înțelesului său real-social-antropologic-artistic/filosofic, cel mai potrivit studiu, predare, învățare-continuă se poate baza pe remodelarea conținuturilor în-formare și construire continuă. Aceste noi progrese/avansuri de înțelegere, procesare a informației, redare și exprimare a semnificației și inovației, pot fi privite ca noi coordonate de valoare ale arhitecturii.

cuvinte cheie

atelier, atelierul de proiectare, arhitectură, educație academică, sinteză, teorie \& practică abstract

Context of the paper is the academic education within master integrated level, and curricula defined by Synthesis of Architectural Design Department (SP), Faculty of Architecture UAUIM Bucharest. Materials and methods defined by the Architectural Design Studio(s) are completed with an integrated overview of research by design, in shaping the Architectural Design (AD) Theory to be fully accessible to students, offering a comprehensive understanding of the scope of education: future professional architects. Results and discussions are focusing on defining a timeline of the notion of $A D$ theory, expression from the professional guild(s) to academia, and backwards, and finally on the definition of research by design, as presenting and sharing innovative results and knowledge through the $A D$ Theory Course within SP. Conclusions: Between the contemporary core discussions of the timeline-history of the domain, a whole new academic education is targeting performant theoretic ideas that supports and results directly from practice, as research by design. As statute process of design contextual lectures and principles, cleanness of shape and new methods approaches- becomes equally important with the autonomy and originality of architectural object and its real-social-anthropological-art/philosophica meanings, the proper study, teaching, lifetime-learning could consist in the reshape of the in-progress contents. These continuous new advances in understanding, process, render and express the meaning and innovation could be regard as new architecture coordinates of value.

\section{keywords}

architectural design studio, architecture, academic education, synthesis, theory \& practice 
1 Către un discurs al teoriei (susținerii) atelierului de design arhitectural (AD)

Multe lucruri s-au spus deja, că împreună înţelegerea teoriei și practicii sunt importante pentru educația viitorilor arhitecţi. Cât de importante sunt, și de asemeni dezbateri între teoreticieni și practicieni au fost stabilite și au constituit baza de conținut a exprimărilor performative, manifestelor, școlilor (de arhitectură), cărților, ideilor construite ale domeniului arhitecturii secolului 20. Incă sfârșitul secolului 20 a reușit să demonstreze prin eforturile câtorva arhitecți teoreticieni și practicieni, că arhitectura este un proces continuu de cercetare pentru și prin design/proiectare - metodă de abordare - cale de design/proiectare - modele de alegere a opțiunilor și de finalitate a formei și locului designului de obiect (arhitectural).

Referindu-ne la o devenire în timp (istorică) a teoriei contemporane a designului arhitectural (AD), sinteze îndrăznețe asupra stilului $A D$ au fost puse în lumină de către mari gânditori din ambele modele statusuri autentice de valoare, și din cele bazate original în practică.

Istoriile arhitecturii recente sunt scrise din exemple construite și statutorii, cum ilustrează cărțile de gândire inovativă cu precedente clădiri care au scris cunoașterea și cunoştinţele timpului - (McCarter \& Pallasmaa, 2012) (Radford et al., 2014) -, colecțiile de idei și noțiuni rescrise ale The Metapolis Dictionary of Advanced Architecture: City, Technology and Society in the Information Age. (Gausa et al., 2003), și Theories and manifestoes of contemporary architecture. (Jencks \& Kropf, 2008), sau hărți ale stilurilor și teoriilor cu rol de modele ca Evolutionary Tree 2000 (Jencks, 2000) (https://archive.org/download/EvolutionaryTree200
0CharlesJencks/EvolutionaryTree2000CharlesJencks. jpg).

Sinteza acestei metode a evaluărilor de design arhitectural constă într-o înţelegere cuprinzătoare integrată a străfulgerărilor conceptuale, conținuturilor, marginilor și finalităţii unui posibil domeniu în continuă perfectare.

Teoriile și reflecțiile filosofice sunt în principal produsul marilor gânditori și/sau a celor care cercetează. Dar într-o înţelegere autonomă a neo_/liberalismului și a profesiei liberale, arhitecții din practica profesională devin din ce în ce mai conștienți de importanța împartășirii cunoștințelor: a celor arhitecturale din birourile personale, instrumente de identificare despre propria abordare și căi conceptuale în editarea și scrierea teoriei $A D$. Câțiva dintre aceștia împărtășesc propria gândire conceptuală prin articole arhitectural-tehnologice din proiecte construite/neconstruite ca Norman Foster and Partners, UK (Norman Foster and Partners, 2019) sau UN Studio, Holland (UN Studio, 2019), sau sub forma unor cărți de arhitectură ca mod de cercetare - MVRDV, Holland (MVRDV, 2000), și mulți alții.

\section{Conceptul acestei teorii pentru academia arhitecturală}

O primă teorie AD care are impact asupra academie arhitecturale este editată și scrisă continuu de breslele arhitecturale naționale și internaționale. Prin eforturile și temele lansate, acestea comunică ce este de luat în considerare ca declarație - în scris - și sub formă de stil-conținut-și-modele de urmat.

Prin apelurile tematice de anuale, bienale pentru proiecte și expoziții, breslele își definesc continuu propria opinie asupra practicii arhitecturale, și poziția asupra modelelor locale/internaționale, promovând valorile întelese pentru prezent.
Multe lucruri s-au spus deja că împreună întelegerea teoriei și practicii sunt importante pentru educația viitorilor arhitecți. Cât de importante sunt, și de asemeni dezbateri între teoreticieni și practicieni au fost stabilite și au constituit baza de conținut a exprimărilor performative, manifestelor, școlilor (de arhitectură), cărților, ideilor construite ale domeniului arhitecturii secolului 20. Incă sfârșitul secolului 20 a reușit să demonstreze prin eforturile câtorva arhitecți teoreticieni și practicieni, că arhitectura este un proces continuu de cercetare pentru și prin design/proiectare - metodă de abordare-cale de

design/proiectare - modele de alegere a opțiunilor - și de finalitate a formei și locului designului de obiect (arhitectural). 
Din aceste valori comunicate periodic, selecția pentru măsurarea impactului inovației a unei astfel de colecții este încă o chestiune de timp. Și aici putem adăuga observația asupra Centenarului (recent) celebrat al Mișcării Bauhaus care încă produce obiecte de valoare contemporane dedicate stilului (prin fanii practicieni arhitecți), contribuind la o colecție internațională a noilor modele fără vârstă. Dacă este vorba aici despre noile-timpuri Bauhaus și a școlii de design, acest impact al continuei inovații va fi măsurată în alți 10 sau poate încă 20 de ani de acum încolo. $O$ simplă explicație a acestei supoziții este durata de aproximativ 50 de ani a evaluării valorii/valorilor cultural-patrimoniale ale arhitecturii - și aici se pot număra mulți ani ai stilului (re)născut după 1990.

Reperele, semnele și locurile sunt și ele supuse selecției funcție de timp și rezonanță, ca cetățenii sau publicul internațional să poată găsi răspuns și reflecție în acestea ca arhitectură existentă. Paseiștii și demolatorii (ca adepți ai pornitului de la zero) sunt extremiștii corespunzători unei piețe complexe dinamice și politice, ce se reflectă asupra arhitecturii ca bun-comun, a valorii de piață în sine, și pentru o creștere economică rapidă. Aici ne putem referi la creșterile economice bruște odată cu mărirea suprafațelor și volumelor de densitate și înălțime mare, și/sau a pieței super globalizate a companiilor multinaționale și întreprinderilor din domeniul arhitecturii, conduse de multe ori de star-architects.

RIBA (Royal Institute of British Architects), ca breaslă locală dar și internațională, subliniază rolul educativ al practicii pentru arhitecții viitorului sustenabil, și sporește rolul acestora în dobândirea valorilor de înrolare (cu drept de semnătură) prin urmarea unei corecte colecții de principii (Royal Institute of British Architects, 2019) și prin editarea de cărți focusate pe permanenta comunicare de la membri cu idei și rezultate inovative, vederi de sinteză și noi înțeleger asupra fondului construit (Dobson, 2014) (Priseman, 2015) (Brown, 2018). Un alt rol internaționalizat al RIBA este acreditarea procesului de învățământ academic arhitectural, garantând eticheta și nivelul 2 (RIBA) pentru absolvenții cu diplomă ai școlilor de arhitectură (12 semestre). Prin această certificare, procesul de educație este periodic verificat ca standarde, rezultate și premise în piața de practică arhitecturală. Astfel absolvenții arhitecți sunt capabili să demonstreze calități/abilități breslelor unde se înrolează, dar și ca angajați ai practicilor internaționale de arhitectură (funcţionând după nivelul garantat de RIBA).

Rolul internațional al declarațiilor comunicate, conceptelor selectate, emergențelor și urgențelor, dar și a sfatului și adnotării asupra tendințelor de sustenabilitate și inovare, este în permanență dezbătut la nivelul breslelor internaționale de la ACE (The Architects' Council of Europe/ Conseil des Architectes d'Europe) si UIA (The International Union of Architects/ Union internationale des Architectes), la ONG-uri/asociații care militează pentru misiuni (arhitecturale) declarative. Rolu breslelor în antrenarea abilităților și îmbunătățirea comunicării rezultatelor în practică s-a mutat dinspre spațiul academic către cel al breslelor profesiunilor liberale în ultimii 30 de ani împreună cu împuternicirea rolului profesioniștilor și a unor figur specifice selectate. In prezent suntem martorii unu proces invers de a acorda sfaturi profesionale dinspre mediul academic, în ceea ce privește un mod structurat de gândire $A D$ către breslele locale și internaționale. Acest demers este susținut de anumite bresle naționale împreună cu parcursul de înrolare în procesul de management al proiectării în practica arhitecturală. Intr-o metodă și manieră 
susținută, în 20 de ani de existență, OAR București (Ordinul Arhitecților din România - Filiala București) este un astfel de exemplu.

Concluzionând pentru un concept al teoriei $A D$ pentru mediul academic arhitectural, am putea spune că este mandatoriu de inclus părerea și viziunea viitoarei practicii, în interiorul căreia rezidă importanța nivelului de educație de master (integrat).

\section{Idei pentru/ și contribuții de la membri mediului} academic către teoria AD SP (curs TP SP)

Departamentul Sinteza Proiectării de Arhitectură (SP) UAUIM a definit scopurile educației nivelului master integrat împreună cu Facultatea de Arhitectură, target-ând pe metodă și abordare academică - cercetare prin design/prin proiect pentru studenți, domenii de studiu, și competențele - abilitățile de obținut și antrenat.

Sinteza este și rămâne un cuvânt cheie pentru nivelul de master integrat, target-at să implice date complexe de tip multi-nivel, implicând metodele definite de abordare (aplicabile de asemeni pentru viitoarea practică profesională), urmărind parcursul propriei cercetări pentru proiect împreuna cu tutorii, și în final aducând împreună experiența dezvoltării propriului model creativ și aplicabilitatea pentru un (de dorit) început de viață de realizări în designul arhitectural.

Criteriile enunțate pentru a acumula cele mai bune rezultate la evaluare sunt: lectura și răspunsul la context, dezvoltarea unui discurs conceptual atractiv și contemporan, gândirea unei structuri spațiale coerente din selectarea complexă a elementelor, dinamica funcțională și de folosință, tehnologia, avansurile în conturarea unei posibile definite sustenabilități în propunerea de design, comunicarea - prezentarea - discursul.

Criteriile sunt conectate cu domeniile de studiu SP în determinarea de a inspira găsirea definirii unui proces dedicat programului de arhitectură din cadrul atelierului $A D$ (atelierului de proiectare): mixitate spațial-funcțională și integrare (contextuală) nouvechi, conversie-extensie-interventie (pentru anul 4 de studiu), experimente arhitectural-structurale și provocări viitoare ca exercițiu avansat pregătitor pentru proiectul de diplomă din anul 6 de studiu (pentru anul 5 de studiu).

Atelierele $A D$ îndrumă întreg procesul de design de proiect ale studentilor - cu prezentări care pun la dispoziție cele mai bune exemple precedente ghidând conceptele, abordare criterială, soluționările și scenariul final. Cursul de teoria proiectului de arhitectură SP este propus să facă conectarea între colectivul academic - studenți și profesori -, în cadrul unor prelegeri de formă deschisă și discuții libere. Prelegerile deschise împărtășesc avansuri emergente și rezultate din cercetarea contemporană și abordările teoretice, rezultate academic educaționale (naționale și internaționale), distincții ale breslelor, rezultate sustenabile și tehnologice speciale din practica arhitecturală, având profesori invitați speciali cu abordări și rezultate complexe din domeniul larg arhitectural, în intenţia să reinstaureze inovația și importanța sa în educație și în continuare, a practicii.

Metoda SP și domeniile de studiu au fost principalele criterii în formularea structurii cursului, pentru a oferi suportul potrivit și să ilustreze conectarea cu practica și relevanța arhitectului ca lider/membru al echipei de proiect (ca lector și traducător al datelor complexe, teoretizator si 
structurator al informației, capabil să dea un răspuns superlativ contemporan ca formă de status în designul arhitectural). Prelegerile și profesorii aleși și invitați în cadrul cursului de teorie $A D$ au fost selectați ca modele contemporane și viitoare pentru domeniul arhitectural național și internațional, având rezultate în designul arhitectural de oferit ca exemple pentru modele cultural profesionale și produse inovative.

In etichetarea criteriilor, criticilor și a noilor cuvinte cheie pentru un dicționar (al unui limbaj de teorie $A D)$, au existat preocupări de listare a noi concepte creative și teorii de noi posibile paradigme de a formula noi colecții de idei poetice, rezultate inovative, modele academice.

Impreună cu strângerea unei colecții de noi elemente valoroase pentru un posibil dicționar și cunoștințe pentru cursul de teoria proiectului (de arhitectură) (teoria $A D=$ curs $T P$ ), colectivul de profesioniști al departamentului SP a promovat cu mândrie, încurajând dialogul, posibilele colaborări, și schimbul de rezultate creative în cadrul spațiului academic (profesori - profesori, profesori studenți).

Cursul de Teoria Proiectului TP (SP, Facultatea de Arhitectură) a reunit între 2017-2018 și 2018-2019, 28 de sesiuni de curs, având 44 de profesori invitați arhitecți (dintre care 37 de la UAUIM) și 5 studenți (împreună cu tutorii) medaliați în competiții internaționale de proiecte, și un număr total de 55 de prelegeri. Designul de curs a inclus 7 sesiuni per semestru, atât pentru anul 4 cât și pentru anul 5 de studiu, în forma de prelegeri de 60-90 minute. Locul principal de desfășurare al cursului a fost Galeria Arhitecților Români Creatori de Patrimoniu Cultural (Gallery of Romanian Architects, Creators of Cultural
Heritage), nivelul 2 UAUIM, o sală ce prezintă o expoziție permanentă de proiecte listate cultural și de valoare arhitecturală, împreună cu promovarea creatorilor arhitecți. Alternativ, pentru un semestru (din total de patru) cursul a fost planificat să se desfășoare independent, statutoriu, în cadrul Sala Frescelor (The Frescoes Hall), primul nivel UAUIM, București. Printre prelegerile noastre invitate, au fost puse în lumină metode și rezultate inovative din educația arhitecturală universitară: Francoise Pamfil - prezentarea principiilor de codare a proiectelor și rezultate concursului EAM BDP - European Architectural Medals for the Best Diploma Projects (Medalia Europeană de Arhitectură pentru cel mai bun proiect de diplomă), organizatori UAUIM, EAAE și ACE (EAM BDP, 2018), Dragoș Dordea, Ana Maria Machedon și studenții medaliați în cadrul workshop POLYAIR RIBA (Polyair, 2017-2018), Dorina OnescuTărbujaru și reprezentanții studenților medaliați la Middle East Solar Decathlon 2018 (EFDEN, 2019), Anca Constantin - prezentarea rezultatelor / proiectelor (Dimitriu \& Constantin, 2017), Marius Voica - prezentarea proiectului VVITA erasmus+, cooperare UAUIM-UNICT-NTNU (VVITA, 2019), Meinhard Breiling (TW Vienna); rolul cercetării recente/emergente/legislative, și a practicii în arhitectură: Ionuț Anton, Ina German, Mihaela Zamfir, Vlad Eftenie, Anca Mitrache, Sergiu Petrea, Vlad Thiery, Carmen Dumitrescu, Dragoș Popescu, Sidonia Teodorescu, Ana-Maria Vesa-Dobre. Sublinierile subiectului înaltă educație și/în conectare cu viitoarea posibilă practică profesională au fost conţinute în prelegerile profesorilor arhitecți: Magdalena Stănculescu, Georgică Mitrache, Daniel Comșa. De asemeni câteva prelegeri au subliniat importanța inovației în/prin ca rezultat al practicii profesionale în conjunctură $\mathrm{cu}$ educația arhitecturală: Dorin Ștefan, Vladimir Arsene, Adrian Spirescu, Zeno Bogdănescu, Mircea Chira, Bogdan 
Tofan, Radu Teacă, Karoly Nemes, lulius Cristea, Marina Mihăilă, Dragoș Dordea, Hanna Derer și invitatul Gabriel Cârstea, de asemeni arhitecții invitați: Ion Chiose, SUA, Michael Perciali, SUA, Wolf Prix, Austria, David Gloster, UK, Boris Koružnjak, Croaţia, Vicente Guallard, Spania.

O altă dimensiune a colecțiilor de informații de valoare, dezvoltate prin cursul TP (așadar de teoria $A D)$ este stabilirea unei baze de date pentru studenți dar și comunitatea academică, de scrieri inovative (unele dintre acestea deja publicate în reviste relevante de arhitectură, și aflate în Clarivate/ISI citation index), documentații de proiecte de design, și date complexe despre inovația și excelența de rezultate în arhitectura raportată. Aproximativ 15 arhitecți-profesori din cadrul SP au autorat 31 de articole listate în Clarivate/ISI citation index în ultimii 8 ani (din 2011), și 16 articole din 2015, în ultimii 5 ani. Mai multe articole au fost raportate ca menționări BDI, ori au fost publicate în reviste locale și naționale de arhitectură.

Din articolele cu indexare-citare Clarivate/ISI, inovația menționată a subliniat importanța teoriei $A D$ din practică și gândirea creativă de design (Banica \& Mihaila, 2016), teoria AD ca cercetare (Mihaila, 2015) (Sfinteș, 2019), metode din cadrul atelierului AD (Mitrache, 2013) (Bărbuică, 2013), abordări în înalta educație (Bărbuică, 2016) (Mitrache, 2012a), abordări tehnologice și tehnice (Comșa, 2011) (Zybaczynski, 2014) (Petrea, 2014), abordări de cercetare filosofică, tradiții și istorii de valoare (Mitrache, 2012) (Mitrache, 2012b) (Voica et al., 2015), principii arhitectural-medicale (Zamfir \& Grigorescu-Zamfir, 2017).
4 Câteva cuvinte pentru un viitor creativ: scriind noi istorii (împreună) pentru teoria $A D$ în cadrul spațiului academic

Teoria Proiectului (de Arhitectură) / Teoria Designului Arhitectural este titlul propus pentru cursul de cunoaștere inovativă, care susține, demonstrează și adună rezultate ale cercetării ca abilitate de susținere a Atelierului de Proiectare (de Arhitectură)/ Atelierul de Design Arhitectural, din cadrul nivelului de master integrat: Departamentul Sinteza Proiectării de Arhitectură, Facultatea de Arhitectură, UAUIM București. Intre miezul discuțiilor contemporane ale devenirii istorice a domeniului, o întreagă nouă educație academică targetează idei teoretice performante care susțin și rezultă direct din practică, ca cercetare prin proiect. Pentru că statutul procesului de design/ proiectare - prelegeri contextuale și principii, curățenia formei și noile metode de abordare- devin egal importante cu autonomia și originalitatea obiectului arhitectural și a înțelesului său real-social-antropologicartistic/filosofic, cel mai potrivit studiu, predare, învățare-continuă se poate baza pe remodelarea conținuturilor în-formare și construire continuă. Aceaste noi progrese/avansuri de înțelegere, procesare a informației, redare și exprimare a semnificației și inovației pot fi privite ca noi coordonate de valoare ale arhitecturii.

\section{afiliere și mulțumiri}

Departamentul Sinteza Proiectării de Arhitectură și Facultatea de Arhitectură, UAUIM București.

Adresăm mulțumiri contributorilor Cursului Teoria Proiectului (de Arhitectură), membrilor comunității academice SP FA UAUIM, și tuturor invitaților profesori ce au susținut conținurile acestor prelegeri cu cunoașterea proprie, împărtășind rezultate inovative în proiectarea arhitecturală și design, cercetare prin proiect și practică, și îndrumând ca mentori studenții nostri, viitori arhitecți. 
Many things have been already

said about how both

understanding theory and

practice are important for

future architects education.

How important they are, and

also debates between

theoreticians and practicians

have been established and

made sense of the

performance, manifestoes,

schools (of architecture), books,

built ideas of the 20th century

architectural domain. Still the

end of the 20th century has

succeeded to demonstrate

through efforts of some

theoreticians and practice

based architects, that

architecture is a continuous

process of: research for and by

design - method approach .

design path - models of

selecting choices - and finality

of the (architectural) object

design shape and place. (english version)

1 Towards a discourse of the theory of (supporting) architectural design (AD) studio

Many things have been already said about how both understanding theory and practice are important for future architects education. How important they are, and also debates between theoreticians and practicians have been established and made sense of the performance, manifestoes, schools lof architecture), books, built ideas of the 20th century architectural domain. Still the end of the 20th century has succeeded to demonstrate through efforts of some theoreticians and practice based architects, that architecture is a continuous process of: research for and by design - method approach design path - models of selecting choices - and finality of the (architectural) object design shape and place.

Referring to a historical timeline of defining a contemporary theory for architectural design (AD), striking overviews on $A D$ style were highlighted by great thinkers both from authenticity valuable statuses and practice based original practices.

Histories of recent architecture are written from built and statutory examples as innovative thinking books with buildings precedents that have written the knowledge timelines - (McCarter and Pallasmaa, 2012) (Radford et al., 2014) -, collections of ideas and rewrote notions as The Metapolis Dictionary of Advanced Architecture: City, Technology and Society in the Information Age. (Gausa et al., 2003), and Theories and manifestoes of contemporary architecture. (Jencks and Kropf, 2008), or maps of relevant role models styles and theories - as Evolutionary Tree 2000 (Jencks, 2000) (https://archive.org/download/EvolutionaryTree200 oCharlesJencks/EvolutionaryTree2000CharlesJencks.j $p g$ ). The synthesis of this method of reviews of architectural design consists in an comprehensive understanding overview of conceptual highlights, contents, margins and finality of a possible continuous perfecting domain.

Theories and philosophical reflections are mainly the product of great thinkers and/or scholars. But in an autonomous understanding of neo_/liberalism and liberal profession, the architects from professional practice are becoming more and more aware of the importance of sharing knowledge: architecture based in their offices, finding tools on how they established their own approach and conceptual path in editing and writing the theory of $A D$.

Some of them are sharing directly conceptual thinking as architectural-technological articles on built/unbuilt projects as Norman Foster and Partners, UK (Norman Foster and Partners, 2019) or UN Studio, Holland (UN Studio, 2019), or as comprehensive books on architecture as research path - MVRDV, Holland (MVRDV, 2000), or/and many many others.

All these new synthetic architecture-practices knowledge materials are offering a right understanding on tendencies, conclusions as innovation contents, recipes and further research as the new core of an in-progress architectural design theory: building a whole new land of inquiries, inceptions and creative atmosphere.

\section{Concept of the theory for architecture academia}

A first theory of architectural design (AD) that have impact on architecture academia is edited and continuous written by the relevant architectural national guilds and the international ones. Through their efforts and launched themes, they communicate what is to be considered as statement 
-in writing-and as style-contents-and-role models -to be followed. Through the launched annual, biennale and thematic call(s) for projects and exhibitions, they continuously define their current opinion on the architecture practice, and position to the local/international models, promoting understood values for present. From these timely periodic communicated values, the selection for measuring the impact of innovation of such elaborated collection is still a question of time. And here we could add the observation of Centenary celebrated Bauhaus Movement that is still producing contemporary valuable styled architectural objects (through fans-practicians/architects), contributing to an international collection of newly without-age models. If there is, here, all about love for a permanent young spirit style, or that is in part a love for an artistic creative times of the original years on Bauhaus born-times and school of design, this impact of continuous innovation is to be measured maybe in another 10 or maybe 20 years from now. $A$ simple explanation on this supposition is the age of about 50 years of evaluating patrimonial value(s) of cultural architecture - and here it is still counting of a re-born style after 1990.

The landmarks, marks and places are also under a question of times and resonance selection, that the citizens or international public to be able to find response and reflection in these, as existent architecture. Past-ridden or demolishers (and starters from the scratch) are extremists to a dynamic and political complex market that reflects on architecture as common-good and real-estatevalue for its own and for fast economical growth. Here we could refer on economical rapid growth together with architecture surfaces and volumes risen high-rise density, and/or to a super globalized market of architecture multinational companies and architecture enterprises lead in many times by stararchitects.

Another internationalized role of RIBA is accreditation of architectural academic education process, guaranteeing the label and status of 2 nd level for graduated diplomats from inclusive 12 semesters schools of architecture education. Through this (kind of) certification, process of education is periodically verified as standards, results and input in architecture practice market. And its graduated architects are able to demonstrate qualities/abilities to enroll guilds and as employees of international practices (functioning and acknowledging RIBA granted label).

International role on communication statements, selected concepts, emergencies and urgencies, but also advising and add-notating on sustainability and innovative trends, is permanently debated from the level of international guilds from ACE (The Architects' Council of Europe/ Conseil des Architectes d'Europe) and UIA (The International Union of Architects/ Union internationale des Architectes), to free NGO association(s) that states for (architectural) statutory missions. The role of guilds in training abilities \& enhancing communication of the results in practice moved from academia into the professional liberal guilds in the last 30 years together with the empowerment of role of professionals and specific figures (architects) selected from them. In present we are witnessing the inverse process of delivering academic advises on optimal $A D$ structured thinking format to local and international guilds. This demarche is also supported at some national guilds together with the enrollment path in managing process of design in architectural practice. In a supported method and manner, in 20 years of existence OAR Bucharest (Romanian Order of Architects-Bucharest Chamber) is such and example. 
Concluding here for a concept of the $A D$ theory for architecture academia, we might say that is mandatory to include feedback and vision of the future practice, within which resides the importance of (integrated) master level education.

3 Ideas for/ and contributions from academics to SP $A D$ theory

Synthesis of Architectural Design Department (SP) UAUIM has defined the purposes of master integrated education together with the Faculty of Architecture targeting on method and approach of scholar research by design for students, domains of study and skills - competences to be achieved and trained.

Synthesis is and remains a key word for master integrated level, as this is targeted to involve multidimensional level thinking - from including knowledge and information from all curricula, collecting and comprising complex multileveled data, involving the defined method of approach (applicable also for future practice), following the path of own research for the project together with tutors, and finally gathering experience on developing own model - creative and applicable for (hopefully) a beginning of a lifetime of architectural design achievements.

Statute criteria for achieving best results on evaluation are: lecture and response to the context, developing an attracting and contemporary conceptual discourse, thinking a coherent spatial structure of complex selection of elements, dynamic functionality and use, technology, advances to possible own defined sustainability in the proposed design, communication - presentation - discourse. The criteria are connected with the SP domains of study in the determination to inspire into finding the definition of a dedicated to process of Architectural Design Studio program of architecture: spatial- functional mixity and new-old integrated conversionextension-intervention (for the 4th year), also specia architectural-structural experiments and future challenges as advanced exercise preparing for 6th year diploma project (for the 5th year).

Architectural Design Studios are tutoring the whole process of students' project designs - with presentations providing the best precedent examples - guidance on concepts, criteria approach, solutions and final script. Architectural Design Theory Course $S P$ is proposed to make the connection between the academia collective -students and professors-, within in an open-form lectures and free discussions. The free-open lectures are sharing emergent advances and results from contemporary research and theory approach, (national and international) academic educational results, guilds awards, special sustainable and technological results in architectural practice, having special invited professors with complex approaches and results from wide architecture domain, in an attempt to reinstate the innovation and its importance in education and (further) practice.

SP method and domains of study were the main criteria in formulating the course structure, for offering the proper support and to illustrate the connection with practice and relevance of the architect as leader/member of the project team (as reader and interpreter of complex data, theorizer and structurer of the information, able of giving a contemporary best response as architectural design status form). The chosen and invited lectures and professors within the AD theory course were selected as contemporary and future role models for nationa and international architectural field, having architectural design results as to be offered as examples for cultural professional model and innovative products. 
In labeling the criteria, critics and fresh keywords for a dictionary (of enhanced $A D$ theory speech), there have been preoccupation on listing new creative concepts and theory of new possible paradigms in order to formulate a new collection of ideas poetics, innovative results, academics models (and backwards).

Together with gathering a collection of valuable new elements for a possible dictionary and knowledge for the $A D$ Theory Course, the collective of the professionals which the SP Department proudly promote, are strengthening the dialog, possible collaboration, and exchange and sharing of creative results within academic space (professors to professors, and professors with students).

$A D$ Theory Course (SP Faculty of Architecture) gathered, within 2017-2018 and 2018-2019, 28 sessions of course, having 44 invited professorsarchitects (from which 37 from UAUIM) and 5 students (together with tutors) awarded in international competition for project, and a number of 55 lectures. The design of the course included 7 sessions per semester, for both 4th and 5 th years of study, in the form of lectures of 60-90 minutes of the course. The place of the happening was mainly Galeria Arhitecților Români Creatori de Patrimoniu Cultural (Gallery of Romanian Architects, Creators of Cultural Heritage), 2nd level UAUIM, a hall that exposes a permanent exhibition of cultural and valuable listed projects together their creators, architects. Alternatively, for one semester (of four), the course was planned to be developed independently, as statutory, within Sala Frescelor (The Frescoes Hall), at the 1st level UAUIM, Bucharest. Among our invited lectures, there were highlighted innovative methods and results from university architectural education: Francoise Pamfil presenting projects encoding principles and results from EAM BDP - European Architectural Medals for the Best Diploma Projects, organizers UAUIM, EAAE and ACE (EAM BDP, 2018), Dragoș Dordea, Ana Maria Machedon and awarded students at POLYAIR RIBA workshop (PolyAir, 2017-2018), Dorina OnescuTărbujaru and the representative students awarded at Middle East Solar Decathlon 2018 (EFDEN, 2019), Anca Constantin presenting results from Pratt Institute (Dimitriu and Constantin, 2017), Marius Voica presenting VVITA erasmus+ project UAUIMUNICT-NTNU (VVITA, 2019), Meinhard Breiling (TW Vienna); role of recent/ emergent/legislative research and practice in architecture: lonut Anton Ina German, Mihaela Zamfir, Vlad Eftenie, Anca Mitrache, Sergiu Petrea, Vlad Thiery, Carmen Dumitrescu, Dragos Popescu, Sidonia Teodorescu, Ana Maria Vesa. The underlines of higher education subject and/ in connection with future possible professional practice were contained in the lectures of architects-professors: Magdalena Stănculescu, Georgică Mitrache, Daniel Comșa. And some lectures have underlined the importance of innovation in/ through result of practice in conjucture with architectural education: Dorin Ștefan, Vladimir Arsene, Adrian Spirescu, Zeno Bogdănescu, Mircea Chira, Bogdan Tofan, Radu Teacă, Karoly Nemeș, Iulius Cristea, Marina Mihaila, Dragoș Dordea, Hanna Derer and invitee Gabriel Cârstea, international invited architects: Ion Chiose, USA Michael Perciali, USA, Wolf Prix, Austria, David Gloster, UK, Boris Koružnjak, Croatia, Vicente Guallard, Spain.

Another dimension of the collection of valuable information, developed through the $A D$ theor course is the establishing a data base for students but also academic community, of innovative writing (some of them published already in relevant architecture journals and Clarivate/ISI citation 
index), documentations on design projects, and complex data on reported innovation and excellence of results in architecture. Also about 15 architectsteachers within SP were reported to authored 31 articles listed in Clarivate/ISI citation index in the last 8 years (since 2011), and 16 articles since 2015, in the last 5 years. Many more articles were reported to be mentioned $B D I$, or been published in architecture based local and national architecture journals. From the top published Clarivate/ISI citation index articles, the mentioned innovation have underlined the importance of $A D$ theory from practice and design creative thinking (Banica and Mihaila, 2016), $A D$ theory as research (Mihaila, 2015) (Sfintes, 2019), $A D$ studio methods (Mitrache, 2013) (Bărbuică, 2013), higher education approaches (Bărbuică, 2016) (Mitrache, 2012a), technology and technical approach (Comsa, 2011) (Zybaczynski, 2014) (Petrea, 2014), philosophical inquiries, valued traditions and history (Mitrache, 2012) (Mitrache, 2012b) (Voica et al., 2015), architectural-medical principles (Zamfir and Grigorescu-Zamfir, 2017).

4 Words for a creative future: writing new stories (together) for an AD theory within academic space

Architectural Design Theory is the proposed title of the innovative knowledge course, that supports, demonstrates and gathers results of the research as the sustain-ability of Architectural Design Studio, for the academic master-integrated level: Synthesis of Architectural Design Department, Faculty of Architecture UAUIM Bucharest. Between the contemporary core discussions of the timelinehistory of the domain, a whole new academic education is targeting performant theoretic ideas that supports and results directly from practice, as research by design. As statute process of design contextual lectures and principles, cleanness of shape and new methods approaches- becomes equally important with the autonomy and originality of architectural object and its real-socialanthropological-art/philosophical meanings, the proper study, teaching, lifetime-learning could consist in the reshape of the in-progress contents. These continuous new advances in understanding, process, render and express the meaning and innovation could be regard as new architecture coordinates of value.

\section{acknowledgement}

Synthesis of Architectural Design Department and Faculty of Architecture, UAUIM Bucharest.

Many thanks are addressed also to the contributors of the Course TP (AD Theory Course) SP, FA UAUIM, academic staff and all our invitees professors that supported the contents of these lectures with their knowledge, sharing innovative results in $A D$ and design, research through design and practice, and also gave mentoring support to our students, future architects.

\section{Citare articol curent / Citation}

(Ro)

Stănculescu M., Mihăilă M., Zamfir M. (2021). Teoria proiectului de arhitectură: de la discurs la educația academică. în Teoria proiectului de arhitectură. Idei construite. SP FA UAUIM. EUIM Editura Universitară Ion Mincu, București.

(En)

Stanculescu M., Mihaila M., Zamfir M. (2021). Theory of architectural design: from discourse to academic education. in Architectural design theory. Built ideas. SP FA UAUIM. EUIM Ion Mincu University Publishing House, Bucharest. 
Banica C., Mihaila M. (2016). Setup Propositions in Architectural Procedia Social and Behavioral Sciences Volume:62. 937-941

Design Thinking: Towards Control and Project Management. Mitrache G. (2012b). Spatial Patterns of Traditional Romanian APPROACHES IN SOCIAL AND HUMANISTIC SCIENCES. 51-54 Houses - A Roadmap to National Specificity. ADVANCED BUILDING Barbuica L. (2016). Architecture Studio Teaching. Transforming MATERIALS AND SUSTAINABLE ARCHITECTURE, PTS1-4 Book Series: Reality. WLC 2016: WORLD LUMEN CONGRESS. LOGOS Applied Mechanics and Materials Volume. 174-177

UNIVERSALITY MENTALITY EDUCATION NOVELTY 2016 (LUMEN Moleavin A., Petrea S.C. (2015). Education, Research by Design and 15TH ANNIVERSARY EDITION) Book Series: European Proceedings Quantum Cosmology. RETHINKING SOCIAL ACTION. CORE VALUES. of Social and Behavioral Sciences Volume:15. 109-121 857-861

Barbuica L. (2013). Towards a New Aural Pedagogy for MVRDV. (2019), MVRDV, Holland. https://www.mvrdv.nl (accesat / Architecture. LOGOS UNIVERSALITY MENTALITY EDUCATION accessed 27.09.2019)

NOVELTY (LUMEN 2013) Book Series: Procedia Social and Norman Foster and Partners. (2019). Norman Foster and Partners. Behavioral Sciences Volume:92.92-97

London, UK. https://www.fosterandpartners.com (accesat / Brown J.B. (2018). Mediated Space. The architecture of news, accessed 27.09.2019)

advertising and entertainment. RIBA Publishing, London, UK. Petrea S.C. (2014). Design in Time of Crisis. EARTHQUAKE HAZARD Comsa D. (2011), Contemporary Ways of Space Envelopment- IMPACT AND URBAN PLANNING Book Series: Environmental Intelligent Building? COMPUTER COMMUNICATION AND Hazards. 231-245

MANAGEMENT Book Series: International Proceedings of Computer Prizeman O. (2015). Sustainable Building Conservation. Theory and Science and Information Technology Volume:5. 300-305 Dobson A. (2014). 21 Things You Won't Learn in Architecture Publishing, London, UK.

School. RIBA Publishing, London, UK. Design in the Heritage Environment. RIBA Dimitriu L., Constantin A.M. (2012). POLYAIR. (2017-2018). Polyair Riba Workshop. http://polyair-5.net University. Argument 4/2012.

(accesat / accessed 27.09.2019)
Radford A., Srivastava A., Morkoc S. B. (2014). The elements of EAM BDP. (2018). European Architectural Medals for the Best modern architecture: Understanding contemporary buildings. Diploma Projects. https://eam.uauim.ro (accessed 27.09.2019) Thames and Hudson Ltd, London, UK.

EFDEN. (2019). EFDEN, Bucharest, Romania. http://efden.org RIBA. (2019). Royal Institute of Architects. London, UK. (accessed 27.09.2019)

http://architecture.com (accesat / accessed 27.09.2019)

Gausa M., Guallart V., Muller W., Soriano F. (2003). The Metapolis Sfintes A.I. (2019). Architecture and Anthropology. Working in Dictionary of Advanced Architecture: City, Technology and Society between Concepts. 3RD WORLD MULTIDISCIPLINARY CIVIL in the Information Age. ACTAR, Barcelona, Spain. ENGINEERING, ARCHITECTURE, URBAN PLANNING SYMPOSIUM Jencks C. A., Kropf K. (2008). Theories and manifestoes of (WMCAUS 2018) Book Series: IOP Conference Series-Materials contemporary architecture. Wiley-Academy, Chichester, UK. Science and Engineering Volume:471 Article Number: 072027.

Jencks C.A. (2000). Evolutionary Tree 2000. archive.org (accesat / VVITA. (2019). VVITA erasmus+ project, partnership UAUIM-UNICTaccessed 27.09.2019) NTNU. http://vvita.uauim.ro (accesat / accessed 27.09.2019)

McCarter R. Pallasmaa J. (2012). Understanding Architecture. Voica M., Mandrescu E.C., Varzaru I.C., Breiling M. (2015). End of $\begin{array}{ll}\text { Phaidon Press, Berlin, Germany. } & \text { E.U.: Sfistofca Steps for Saving a Traditional Community. URBANISM }\end{array}$ Mihaila M. (2015). Architecture Numbers, Figures and Counting: ARCHITECTURE CONSTRUCTIONS Volume:6 Issue:4. 5-16 People, Models and Spaces. RETHINKING SOCIAL ACTION. CORE UAUIM. (2019), UAUIM. http://uauim.ro (accesat / accessed VALUES. 801-806 27.09.2019)

Mitrache A. (2012). The Cula House - A Specific Case Study. UN Studio. (2019). UN Studio. Holland. https://www.unstudio.com ADVANCED BUILDING MATERIALS AND SUSTAINABLE (accesat/accessed 27.09.2019)

ARCHITECTURE, PTS 1-4 Book Series: Applied Mechanics and Zamfir M.V, Grigorescu-Zamfir M. (2017). A checklist for assessing Materials Volume. 174-177 dementia-friendly design: Architecture as non-pharmacological Mitrache A. (2013). Spatial sensibility in architectural education. RD mean in assistance of patients with dementia. EUROPEAN WORLD CONFERENCE ON LEARNING, TEACHING AND PSYCHIATRY Meeting Abstract: EV0806 Volume:41. S667-S667

EDUCATIONAL LEADERSHIP Book Series: Procedia Social and Zybaczynski V. (2014). The Evolution of Chromatics in Bucharest Behavioral Sciences Volume:93. 544-548 Since the 19th Century: Background for Developing a Coherent Mitrache G. (2012a). Sustainable management in academic Colour Concept. SOCIOINT14: International Conference on Socia architectural research. WORLD CONFERENCE ON BUSINESS, Sciences and Humanities. 550-558 

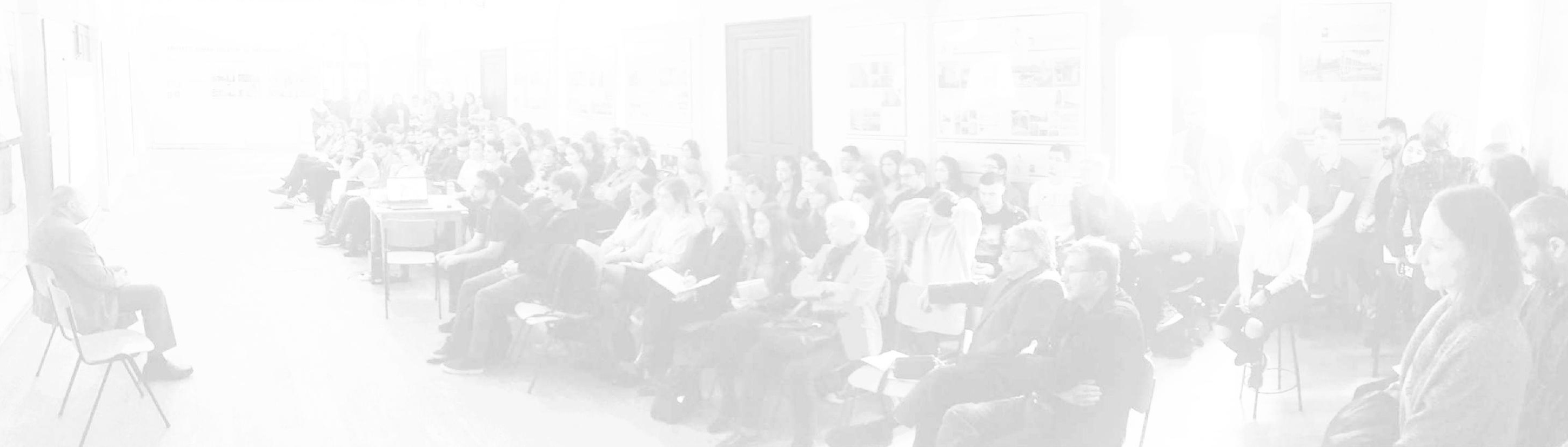


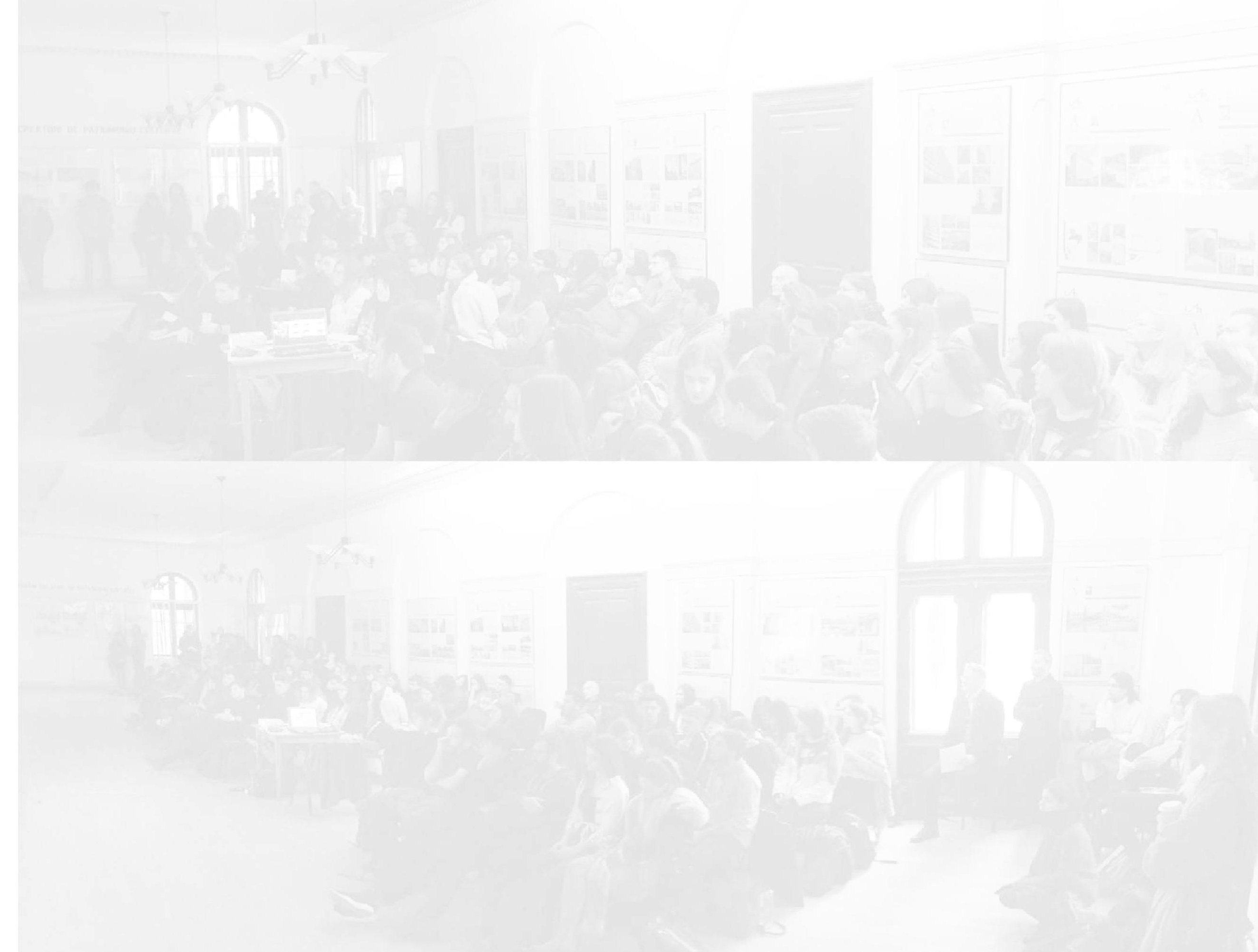

